\title{
Distinguishing: Appointment, Recognition of Children and Ratification of Children Based on Law Number 23 of 2006 concerning Population Administration
}

\author{
Habib Adjie \\ Universitas Narotama Surabaya, Indonesia \\ Email: adjieku61@gmail.com
}

\begin{abstract}
Article $47(1)$ of Law No 23 of 2006 on the Administration of the Population (Adminduk) provides that the adoption of children is a legal act to transfer the rights of the child from the families of parents, legal guardians and others responsible for the care, education and bringing of children into the families of their adoptive parents by decision of the Court Basing this child acceptance on the concept or limitation of child adoption is a legal act with certain law-controlled goals and aims and inevitable legal consequences, such as the bodily and psychological responsibility of the child he or she accepts. Kid Recognition is a father's recognition of his kid born from lawful marriage with the agreement of the biological mother of the child. Kid acknowledgment is meant to provide the child a biological father/father, as well as legal civil ties. The provisions mentioned in the Elucidation of Article 49(1) of the Adminduk Law are acknowledgments that can only be made by the father/father, in this case there is no mother's acknowledgement; in other words, it is not automatically necessary to prove that the child was not born by the mother concerned. Elucidating Article 50(1) of the Child Legalization Administration Law is the ratification of the status of a child born outside the legal marital bond while registering the marriage of the child's two parents. Article 50(1) of the Administrative Law requires parents to notify the child's ratification to the Implementing Agency no later than 30 (thirty) days after the child's father and mother marry and acquire a marriage certificate. Child Recognition or Child Ratification can be performed for children born outside formal marriage. If the child's acknowledgement is restricted to a disclosure from his biological father, accepted by his birth mother, without being followed by the parents' marriage, yet in the Child Legalization, the child's mother and father are married. When documenting the wedding, the youngster is recognized as their biological kid. And this kid's ratification is a legal endeavor (rechtsmiddel) to offer a position as a legitimate kid through marriage by his parents.
\end{abstract}

Keywords: Adoption, Child Recognition and Child Ratification.

\section{A. INTRODUCTION}

Humans as social creatures have the instinct to partner with each other. With this instinct, humans want a small community, namely a family, so humans must carry out a marriage to form the society (Khasinah, 2013). Every human being who decides to carry out a marriage generally aims to create a happy and eternal family based on God Almighty. Union also seeks to get a child or legal offspring to continue their lineage (Hadikusuma, 2003). According to the natural mind of an intelligent person, a child is a child that his parents await to continue their offspring, bind and vent their outpouring of human affection (Istiqomah \& Mukhlis, 2016). With the presence of children as the successor of the lineage, it is hoped that it will increase the happiness of married couples in their small family. The reason for obtaining offspring is often 
why a man and a woman decide to form a family (Matondang, 2014). Although having children is not the only reason for creating a marriage, in reality, the absence of a child is the reason for the imperfection of a family. It is often the reason for breaking up a marriage. To prevent the termination of marriage due to the absence of offspring, the adoption of children is carried out (Matuankotta, 2011).

In Indonesia, adoption is not a new thing because many married couples have adopted children differently and with different motivations (Pratiwi, 2016). The Republic of Indonesia Government Regulation No 54 of 2007 on the Implementation of Child Adoption defines an adopted child as one whose right is transferred from a child's parent, legal guardian, or other person responsible for the child's care, education, and rearing into an adoptive parents' family environment on the basis of adoption. The Government Regulation No. 54 of the Republic of Indonesia, 2007, on the Implementation of Child Adoption, states in Article 1(2), "Child adoption is a legal act which transfers a child from the parent's environment, legal guardian or the person responsible in charge of child care, training and upbringing into the adoptive family." (Budiarto, 1985).

Population Management Law No. 26, 2006, was adopted and enacted on 29 December 2006 (State Gazette of the Republic of Indonesia of 2006 Number 124 and Supplement to the State Gazette of the Republic of Indonesia). Significantly, the law controls Population Administration to guarantee that all Population Events and Significant Events of Indonesians who require legitimate proof of administration and recording, are protected, recognized, and determined by personal status and legal status, according to requirements. The Act or legislation controls the management and registration of population events and major events involving Indonesian residents and citizens which the Implementing Agency later submits as evidence or as official documents (Silalahi, 2007).

To ensure the implementation of Population Administration, that the performance of Population Administration (Effendi, 2006) aims to:

1. offer legal identification and legal certainty for resident papers in the event of a Population Event or a Significant Event.

2. Protect the status of civil rights of the population.

3. Provide population data and information nationally regarding Population Registration and Civil Registration at various levels in an accurate, complete, up-to-date, and easily accessible manner so that it becomes a reference for policy formulation and development in general.

4. Establishing a unified and orderly National Population Administration, and

5. provide population data that becomes an essential reference for related sectors in implementing every government, development and community activity.

Reviewing the substance of Law Number 26 of 2006 and which is declared revoked and declared invalid, only relates to the recording and preparation of legal documents for:

1. Birth;

2. Death; 
3. Marriage;

4. Divorce;

5. Change or Addition of Surname.

The term "Important Events" refers to events that occur to a person, such as birth, death, stillbirth, marriage, divorce, child recognition, child ratification, child adoption, and name change. Additionally, there is the possibility of changing one's citizenship status. Because the Important Event concerns a person's civil status, which was formerly regulated in Book One, Chapter Two, Part Two, and Chapter Three of the Civil Code (Burgerlijke Wetboek voor Indonesia, Staatsblad 1847: 23), the event or incident is included in the section or regulation of Populate (Hardjawidjaja, 1979).

Although the essence of Law Number 26 of 2006 regulates the recording of Important Events experienced by Indonesian Residents or Indonesian Citizens according to the applicable legal rules, in the Explanation section, the law regulates and provides limitations or understandings related to Legal Events. which are held and mentioned in the explanation, among others:

1. Adoption of children (Explanation of Article 47 paragraph (1).

2. Child Recognition (Article 49 section (1).

3. Child ratification (Article 50 paragraph (1).

These three things need to be explicitly studied because Law No. 26 of 2006 has provided definitions and limitations that can change the existing boundaries or understandings. However, the brief mention of these three things is contained in the explanation relating to Civil Registration for the Adoption, Recognition and Ratification of Children.

\section{B. METHOD}

The author conducted study in the area of normative juridical law. The term "normative jurisprudence" refers to legal study that views the law as a system of norms, namely the principles, norms, and rules of legislation (Budiarto, 1985). These research analyses are prepared in accordance with the study's legal criteria, specifically Law Number 23 of 2006 on Population Administration.

\section{RESULT AND DISCUSSION}

\section{Child Adoption}

Under Article 47(1) of Law No. 23 of 2006 on the administration of populations, adoption is defined as "a legal action to transfer children's rights from their parents' family environments, legal guardians or others responsible for caring for, training and education of their adoptive parents in the family environment, based on coparenthoods".

Under the definition or limit of adoption, it is a legal act with specified purposes that necessarily has legal implications; for example the person who takes the child is fully responsible for the physical and mental well-being of the child (Budiarto, 1985). 
Besides adoption, which is a legal act, there is also adoption. In this connection, it raises the question of whether adoption and adoption constitute the same legal act? The end of the aims and objectives of Child Adoption and Adoption is the same, namely for the physical and spiritual well-being of the adopted or adopted child, but in terms of different requirements (Prasmuktio, 1988). The definition of adoption as such requires everyone to be able to adopt a child after fulfilling the specified conditions. In contrast, adoption as stipulated in the Staatsblad 1917: 129, and it can be concluded that adoption can only be carried out by (Meliala 2007):

a. a husband and wife who do not have children.

b. A widower who has no sons.

c. A widow who does not have a son as long as her late husband does not leave a will that does not want his widow to adopt a child.

d. Male Chinese who have no wife and no children and have not been adopted by someone else.

In adoption, the civil relationship that comes from descent due to birth between parents or their families is by blood and marriage with the adopted child. The adopted child, because of the law, can use the surname of the adopting parent. Thus, adoption can be carried out if it meets the requirements specified in the Staatsblad 1917: 129, in other words, not everyone can adopt, but for the adoption of a child, it can be done without seeing the same or almost the same provisions as those mentioned in the adoption (Amin \& Hadi, 2020).

The adoption of this child has a different definition or definition if it is associated with adopting a child in or according to customary law and Islamic law. The adoption of children under customary law is related to the family system in Indonesian society, namely Patrilineal, Matrilineal or Parental. However, adoption based on the family system does not have to be like that. In line with the times, there has been much jurisprudence that has placed legal relations in the adoption of the child (for example: that according to Customary Law (in the West Java area), a person is considered an adopted child if it has met the requirements: being taken care of, circumcised, sent to school, and married off, where the adopted child comes from the family of the adoptive mother, then the youngster has the right to inherit his adopted parents' property (Rais, 2016).

In Islamic Law, the requirements for Child Adoption are different, with provisions for Adoption, Customary Law or other favourable legal rules relating to Child Adoption. In Islamic law, adoption of a child is meant only to raise children (Faradz, 2009), so that in Islamic law, a child who his adoptive parents adopt:

a. to maintain a friendly relationship with his biological parents, meaning that the adopted child must still know who his birth parents and other siblings are, this must be done to maintain the lineage or lineage of the child in question.

b. Not allowed to use the name or additional name or surname of the adoptive parents.

c. Remain domiciled as heirs of their biological parents.

d. Continue to inherit property from their biological parents. 
e. The adopted kid will get an inheritance from his or her adoptive parents in the form of a required will that does not exceed 1/3 (one-third) of the adoptive parents' assets.

In reality, however widespread, the definition of Child Adoption is common in legal practice (both in accordance with Article 1(9) of the law of 2002 on child protection and the elucidation of Article 47(1) of the law of 2006 on the administration of the population), as well as Customary Law, Islamic Law,) with adoption, when in fact the legal actions are different, although, in the end, both aim for the physical and spiritual welfare of the child who is adopted or adopted by the person concerned.

To be more practical, these requirements are better mutatis-mutandis for Child Adoption or adoption, meaning that if there are conditions that are not following the values that live in society, there is no need to use them, for example, the provisions of Article 14 Staatsblad 1917: 129, which confirms the severance of civil relations. between an adopted child and both parents or blood relatives and by marriage with the adopted child, because if this is proven, It will be subject to the requirements of Article 79 of Law No. 23 of 2003 on Child Protection, which states that adopting a child violates Article 39 paragraph (1), and (4) would face a maximum punishment of 5 (five) years in jail or a fine of Rp. 100,000,000.- (one hundred million) rupiah.

Article 47 of Law Number 23 of 2006 concerning Population Administration regulates the Registration of Child Adoption, namely:

1) Registration of child adoption is carried out based on a court order at the applicant's place of residence.

2) The resident shall notify the Implementing Agency that issues the Birth Certificate Excerpt of the child adoption as described in paragraph (1) no later than 30 (thirty) days after obtaining a copy of the court order.

3) The Civil Registration Officer inserts a minor remark on the Birth Certificate Register and Birth Certificate Quotation based on the report referred to in paragraph (2).

\section{Child's Confession}

Kid Reconnaissance has been defined as a parental identification of his child born outside legal marriage with the consent of his biological mother in Article 49(1) of Law 23 of 2006 on Population Administration. Religion and government are both establishing marriage institutions; all marriage criteria must be satisfied in order to perform legal weddings (Prawirohamidjojo \& Pohan, 1995). In Article 2(1) and (2) of the Law No. 1 of 1974 on marriage, it is therefore underlined that marriage is legitimate if carried out in accordance with the religions and beliefs of the parties.

There is also what is referred to as a child born outside of a legal marriage in some situations, which means that the parents do not marry according to the rules of Article 2 paragraph (1) and (2) of the Marriage Law; hence, the kid born has a legal status. As an illegitimate kid, in the sense of a kid born outside of his parents' legally recognized marriage. 
Recognize the kid as intended in order for the kid to have a biological father; moreover, a civil connection will develop legally. The rules in Article 49(1) of Law No. 23 of 2006 governing the administration of population are a recognition solely by the father; in this case, no acknowledgement by the mother is required; in other words, it is not necessary to establish automatically that the child was not born to the mother in question.

This is understandable given that a child born outside of a formal marriage has just a civil tie with his original mother and her family. Recognize the kid only with the approval of his biological mother; without the approval of the kid's birth mother, the kid's father or father cannot acknowledge the kid.

According to Article 49(1) of Law 23 of 2006 on the administration of populations, within 30 (thirty) days from the date of an acknowledgement letter from father of the infant, which was received by the mother of the child involved, the parent should inform the implementing agency.

In this regard, the child's acknowledgement letter, which the child's biological mother approves, is better made in the form of a notary deed for the perfection of the child's acknowledgement (Adjie, 2020) and can be strong evidence for the parties. In addition, before the confession is declared before a Notary, to obtain objective evidence, it is advisable to do a DNA (deoxyribose Nucleic Acid) examination first, between the father who will acknowledge the child, his biological mother and his child because otherwise it is done like this, worried for the sake of saving someone's name or family, there is a man or a father who is willing to admit a child who is not his child.

\section{Child Authorization}

Child Legalization is described as a confirmation of the status of the baby who, despite recording the marriage of two parents, is born without the legal connection in Article 50, paragraph (1) of Law No. 23 of 2006 concerning Population Administration. Article 50(1) of Population Administration Act No 23 of 2006 states that the parents shall inform the child legalization Agency no later than 30 (thirty) days after the child's father and mother get married, and shall get the marriage certificate.

Child Recognition or Child Ratification can be performed on children born outside of a formal marriage. If the child's acknowledgement is restricted to a disclosure from his biological father that is accepted by his birth mother, without the parents marrying, yet in Child Legalization, the child's mother and father marry. When the wedding is recorded, the child is identified as their biological child. And the Ratification of the Kid is a legal attempt (rechtsmiddel) by the kid's parents to establish him as a legitimate child via marriage.

\section{CONCLUSION}

In the current development of Indonesian family law, particularly those pertaining to children, it has been simplified; both Law Number 1 of 1974 on Marriage and Law Number 23 of 2006 on Children recognize only 1. Legitimate children, defined as children born as a result of, in, or during a legal marriage (Article 42 of Law 
Number 1 of 1974 concerning Marriage). 2. Children born outside of legal marriage or children whose parents are not legally married and have only civil contacts with their mother and her relatives or mother's family (Article 43 paragraph (1) of Marriage Law No. 1 of 1974).

Children born outside of a legal marriage can be recognized (Child Recognition) by the father/father (Explanation of Article 49 paragraph (1) of Law Number 23 of 2006 concerning Population Administration) or legalized (Child legitimacy) through the parents' marriage (Explanation of Article 50 paragraph (1) of Law Number 23 of 2006 concerning Population Administration). As noted before, knowledge of the legal status of children is advantageous for Notaries when parties request a Notary (appearing) to prepare a Deed of Statement of Heirs and the distribution of inheritance rights for the heirs.

\section{REFERENCES}

1. Adjie, H. (2020). Unifikasi Pembuatan Keterangan Waris yang Dibuat di Hadapan Notaris. Yogyakarta: Nas Media Pustaka.

2. Ali, Z. (2021). Metode Penelitian Hukum. Sinar Grafika.

3. Amin, M. N., \& Hadi, A. (2020). Tinjauan Hukum Islam Terhadap Pengangkatan Anak (Adopsi) dan Pembagian Harta Warisnya. Ummul Qura, 15(1), 13-34.

4. Budiarto, M. (1985). Pengangkatan Anak Ditinjau Dari Segi Hukum. Akademika Pressindo.

5. Effendi, W. (2006). Adminduk dan Kriminalisasi Penduduk. Kompas 19 December 2006.

6. Faradz, H. (2009). Pengangkatan Anak Menurut Hukum Islam. Jurnal Dinamika Hukum, 9(2), 191-198.

7. Government Regulation of the Republic of Indonesia Number 54 of 2007 concerning Implementation of Child Adoption.

8. Hadikusuma, H. (2003). Hukum Pernikahan Indonesia. Bandung: Mandar Maju

9. Hardjawidjaja, J. (1979). Hukum perdata. Faculty of Law and Public Knowledge, Universitas Brawijaya.

10. Istiqomah, I., \& Mukhlis, M. (2016). Hubungan Antara Religiusitas dengan Kepuasan Perkawinan. Jurnal Psikologi, 11(2), 71-78.

11. Khasinah, S. (2013). Hakikat Manusia Menurut Pandangan Islam Dan Barat. JURNAL ILMIAH DIDAKTIKA: Media Ilmiah Pendidikan Dan Pengajaran, 13(2).

12. Law Number 1 of 1974 concerning Marriage.

13. Law Number 26 of 2006 concerning Population Administration.

14. Matondang, A. (2014). Faktor-faktor yang mengakibatkan perceraian dalam perkawinan. JPPUMA: Jurnal Ilmu Pemerintahan dan Sosial Politik UMA (Journal of Governance and Political Social UMA), 2(2), 141-150.

15. Matuankotta, J. K. (2011). Perlindungan Hukum Terhadap Anak Angkat Dalam Memperoleh Kejelasan Status Hukum Melalui Pencatatan Pengangkatan Anak (Suatu Tinjauan Dari Perspektif Hak Asasi Manusia). Sasi, 17(3), 70-79. 
16. Meliala, D. S. (2007). Perkembangan Hukum Perdata Tentang Orang dan Hukum Keluarga. Nuansa Aulia.

17. Pramuktio, A. (1988). Perbandingan Pengangkatan Anak dan Adopsi (Doctoral Dissertation, Universitas Airlangga).

18. Pratiwi, I. P. (2016). Akibat Hukum Pengangkatan Anak Yang Tidak Melalui Penetapan Pengadilan. Kumpulan Jurnal Mahasiswa Fakultas Hukum.

19. Prawirohamidjojo, R. S., \& Pohan, M. (1995). Hukum Orang dan Keluarga: Personen En Familie-Recht. Surabaya: Airlangga University Press.

20. Rais, M. (2016). Kedudukan Anak Angkat dalam Perspektif Hukum Islam, Hukum Adat dan Hukum Perdata. DIKTUM: Jurnal Syariah dan Hukum, 14(2), 183-200.

21. Silalahi, H. T. (2007). Masalah pada UU Adminduk. Kompas. Wednesday, 4 April 2007. 